\title{
Ou-Testamentiese perspektiewe ten dienste van die besinning oor die vrou in die kerklike amp
}

\author{
J A LOADER
}

Die problematiese van hierdie onderwerp en die aard van die tekste waarmee ek moes werk, veroorsaak dat my bydrae tot die diskussie in sommige opsigte as negatief en in ander opsigte as indirek bestempel moet word. Die 1977-Predikantevergadering het gevra na die Bybelse perspektiewe oor die vrou in die amp. Daaruit blyk een ding duidelik: Die teologiese probleem oor die vrou in die amp het ons na die Bybel gedryf. Dit is sekerlik uiting van die sentrale moment van enige Reformatoriese teologiebeoefening - om eers te luister na wat die Bybel te sê het. Hiermee gee ons te kenne dat ons tot geen teologiese beslissing wil kom sonder dat ons die Bybel beluister het nie. Hoewel geen teologie daarsonder beofen kan word nie, is die blote begeerte en eers die Ou Testament en die Nuwe Testament te beluister nog geen waarborg dat ons op die regte pad is nie. Want om die Bybelse getuienis (in hierdie geval die Ou Testament) aan te hoor, moet ons hom reg kan hanteer - wat weer inhou dat ons ons rekenskap moet gee van die feit dat ons hier met literêre produkte te doen het wat elk 'n boodskap dra. Wanneer dit uit die oog verloor word, kan ons nie die funksionaliteit bepaal van die gegewens wat die Ou Testament oor ' $n$ bepaalde probleem bied nie. En dit kan weer lei tot ' $n$ onkritiese afleiding van norme en riglyne wat die $\mathrm{Ou}$ Testament nie bevat nie. Nou lyk dit vir my noodsaaklik om ons oë juis hiervoor oop te hou wanneer ons die Ou Testament ter sprake bring in die konteks van die kerklike ampte en spesifiek die vraag na die vrou in die amp.

Een moontlikheid, dié een wat oënskynlik voor die hand lê by 'n taak soos myne, sou wees om so noukeurig as moontlik ' $n$ beeld te probeer rekonstrueer van die sosio-religieuse posisie van die vrou in ou Israel. Hiervoor sal die Ou Testament natuurlik die vernaamste bron wees. Sedert baie dekades is sulke studies dan ook inderdaad gedoen, byvoorbeeld deur M Löhr (Die Stellung des Weibes zu YahveReligion und Kult, Liepzig 1918), G Beer (Die soziale und religiöse Stellung der Frau im israelitischen Altertum, Tübingen 1919) en P Cruveilhier ("Le droit de la femme dans la Genèse et dans le recueil de lois assyriennes", RB 36, 1927, pp 350-376). Die bekendste en invloedrykste eksemplaar van hierdie benadering is die standaardwerk van Roland de Vaux oor die Israelitiese kultuurgeskiedenis, Les institu- 
tions de l'Ancien Testament, Parys 1959. Die beeld wat De Vaux rekonstrueer, kom op die volgende neer:

Die vrou geld as die sosiale ondergeskikte van die man. Dit blyk uit die aanspreekvorme $b a^{c} a l$ en' $\bar{d} \bar{d} \bar{n}$ waarop die Huweliksformulier ' $n$ teologiese beroep doen, en uit haar juridiese posisie soos gereflekteer in die wetskodekse. In die Dekaloog geld sy byna as die besitting van die man; volgens die skeidingsreg mag haar man haar verstoot maar nie omgekeerd nie; geen vrou het erfreg nie, behalwe by ontstentenis van manlike erfgename - en dan nog om die ontwil van die ontslape man, terwyl 'n erfgename se huweliksmoontlikhede dan nog ingeperk word (Num 27:1-11; 36:1-13). Verder het selfs die gelofte van 'n vrou geen geldingsreg as dit deur 'n manlike gesagspersoon ingetrek word nie (Num 30:4-17). Haar deelname aan die openbare lewe was prakties nul, met 'n paar uitsonderinge waarop sowel berigte as verhale toespeel (byvoorbeeld Debora, Jaël, die wyse vrou van Abel-Bet-Maäga in II Samuel 20, Isabel, Atalia en Hulda, die rol van die koninginmoeder tydens die monargiese periode waarvan ons in die Samuel- en Koningsboeke lees, en die Esternovelle). De Vaux versprei sy behandeling van hierdie gegewens oor verskeie hoofstukke.

Teenoor hierdie sosio-juridiese minderwaardigheid van die vrou staan daar ' $n$ temperende tendens waaraan De Vaux ook aandag gee. Waardering vir die vrou styg wanneer sy kinders (veral seuns) baar, maar dit beteken vanself dat haar status verdonker as sy geen kinders het nie (vergelyk die verhale oor Sara en Ragel). Die waardering vir die vrou geskied dus aan die hand van ' $n$ funksionele beoordelingsnorm en nie ' $n$ prinsipiële nie. Haar funksionele waarde blyk duidelik uit die huwelike van Salomo wat niks anders as politieke detentemaneuvers was nie. Die temperende tendens i v m die vrou se minderwaardigheid blyk ook uit die wetskodekse waar die vrou se eer beskerm word teen aantasting deur haar man (op beperkte skaal) en haar kinders (Eks 20:12; 21:17; Lev 19:3; 20:9; Deut 21:18-21; 27:6). Ook die wysheidsliteratuur gee hieroor enige inligting, waar kinders voorgeskryf word om hul moeder te respekteer ((byvoorbeeld Spr $19: 26,20: 20 ; 23: 22 ; 30: 17)$. In die Spreukeboek word die vrou ook funksioneel gewaardeer, maar later sal ons weer op dié boek terugkom. Van 'n temperende tendens kan ook gepraat word wanneer daar sprake is van die liefde van 'n man teenoor sy vrou. Voorbeelde hiervan is die liefde van Isak vir Rebekka, van Elkana vir Hanna (I Sam 1), en van Sigem vir Dina (Gen 34 - hoewel dit hom nie laat terugdeins het daarvan om sy Israelitiese geliefde te verkrag nie). Dan is daar nog die besondere vryheid waarmee die jong meisie in die merkwaardige gedigte van die boek Hooglied optree, sodat sy as die volkome gelyke van die jongman verskyn. Hierdie voorbeeld neem af in waarde as getuienis vir die ou Israelitiese sosiale opset wanneer 
bedink word wat die funksie van die liedere is, $\mathrm{nl}$ gewone erotiese liriek. Dan kan ook nog vermeld word dat die weduwees in Israel wetlik beskerm is (Eks 22:21; Deut 10:18; 24:17, 21; 26:12-13; 27:19). Dié eis is egter skromelik in die praktyk verwaarloos (vergelyk die sosiale kritiek van die profete, Jes 1:10-17; 10:1-4; Jer 7:1 v v; Sag 7:7-14 ea). In elke geval word ook wat dit betref, nie op die posisie van die vrou gefokus nie en geld sy as één weerlose kategorie naas die wees en die vreemdeling, vergelykbaar met soortgelyke reëlings in ander oudoosterse wetskodekse (vgl J A Loader, Aspekte van menslike mag in die Ou Testament, diss. Gronigen 1975, pp 54-55; C van Leeuwen, Le développement du sens social en Israël, diss. Assen 1954, pp 81-82).

Ek het probeer om 'n getroue weergawe van De Vaux se rekonstruksie te bied, hoewel ek ook voorbeelde van my eie bygevoeg het. Nou is dit volkome legitiem om so 'n sosio-historiese beeld te probeer rekonstrueer in 'n boek wat die kultuurgeskiedenis van ou Israel wil beskryf. Selfs in hierdie opsig is daar probleme met De Vaux se boek. Soms gebruik hy verskillende gegewens uit verskillende fases van die sosiale ontwikkeling van Israel onder een tematiese aspek, sodat ' $n$ duidelike beeld nie verkry word van die veranderinge in die geskiedenis nie (sonder om te beweer dat De Vaux nie met ouer en jonger gegewens reken nie). In ander gevalle skets hy wel die ontwikkelingsgang van verskynsels. Dus moet mens fyn diskrimineer wanneer jy sy boek gebruik. Maar dit is nie die vernaamste probleem van sy boek in ons huidige konteks nie. Die gevaar lê by wat ons daarvan máák. Dit sou 'n totaal onverantwoorde hantering van Bybelse gegewens wees wanneer ons so'n rekonstruksie van die sosiokulturele posisie van die vrou in Israel gaan hanteer as 'n teologiese waardering van die onderwerp "die vrou in die Ou Testament" of van haar sogenaamde "religieuse posisie in die Ou Testament". Natuurlik kan sulke historiese gegewens waarde hê by die interpretasie van wat ' $n$ bepaalde verskynsel in teologiese opsig sou beteken, maar dit is alleen één aspek wat as hùlpdissipline 'n bydrae kan maak. Daarom sou ons kritiek kon uitspreek teen die titel wat De Vaux self aan sy Franse boek gegee het - dit gaan hom nie om die instellings van die $\mathrm{Ou}$ Testament nie, maar om dié van Isreal. Die titels van die Nederlandse en Engelse vertalings is in dié opsig korrekter (Hoe het oude Israël leefde en Ancient Israel), hoewel die Nederlandse titel weer 'n ongelukkige subtitel bygekry het. Dit gaan hier (soos De Vaux kennelik self bedoel) nie om 'n eksegeties-teologiese bepaling van wat die $\mathrm{Ou}$ Testamentiese interpretasie van die vrou se posisie is nie, maar om ' $n$ historiese bepaling van hoe ou Israel se sosiale struktuur daar uitgesien het. En wat ou Israel gedóén het, is nie gelyk aan die bóódskap van die Ou Testament nie.

Die tweede invloedryke voorbeeld van hierdie benadering wat ons sal moet bekyk, is die behandeling van Albrecht Oepke in ThWNT 
onder die inskrywing gynē. Hy behandel die posisie van die vrou in die Umwelt van die Nuwe Testament, wat vir hom dan ook die Ou Testament insluit, dan die probleem in die Nuwe Testament, en ten slotte die sakrale en gemeentelike funksie van die vrou. Sover dit die Ou Testament betref, skets ook hy haar sosiale posisie, terwyl hy ook wys op die twee pole van minderwaardigheid en tempering daarvan. Hy doen egter moeite om waar moontlik die religieuse aspek van hierdie situasie uit te wys. In die Dekaloog word die vrou nie tot die sabbatsrus verplig nie; huwelikstrou word van haar, maar nie van haar man nie, verwag. In teenstelling tot die res van die ou Ooste mag sy nie kultiese diens verrig nie. Tot die temperende pool reken hy die feit dat sommige vroue met sterk persoonlikhede wel hul invloed kon laat geld (bv Sara, Rebekka, Migal en Abigail), terwyl hy ook nie nalaat om die betekenis van die rigteres Debora in die openbare lewe te noem nie. Ten spyte daarvan dat die priesterskap die man se prerogatief was, wys Oepke in sy afdeling oor die sakrale posisie van die vrou "in die Ou Testament" daarop dat die vrou tog tot mindere diens in die tabernakel toegelaat is (Eks 38:8), en dat sy deelgeneem het aan kultiese volksfeeste (Deut 12:12, II Sam 6:19), reidanse (Rig 21:21), die offermaaltyd (I Sam 1:4-5) en veral die pasga. Daarbenewens beklemtoon hy ook die funksies van profetiesbegaafde vroue soos Mirjam, Hulda en Noadja.

By die beoordeling van die bruikbaarheid van hierdie skets kom verskeie vrae na vore. Eerstens is Oepke se voorstelling ook alleen 'n rekonstruksie van kultuurhistoriese verhoudings in ou Israel. $\mathrm{Hy}$ haal egter diverse gegewens uit vroeëre en latere tekste deurmekaar sodat die historiese perspektief nagenoeg genegeer word - en dit is nou juis die belangrike in so 'n skets. Hy gee hom nie hieroor rekenskap nie (wat De Vaux wel doen omdat hy 'n kultuurgeskiedenis wil skryf, al is sy aanbieding nie altyd ewe goed in historiese reliëf nie). Daarom kan Oepke ook talle geïsoleerde gegewens verskaf sonder om ag te slaan op die funksie wat sulke motiewe in verskillende literêre kontekste het. Hy maak (anders as De Vaux) die aanspraak om 'n stuk teologie in 'n teologiese woordeboek te skryf. Dit is ' $n$ volkome onhoudbare posisie wat te wyte is aan die prinsipes waarvolgens die ThWNT ingerig is. Woorde word as uitgangspunt geneem en hul teologiese relevansie word dan na bewering nagevors. Dit word onwetenskaplik aangeneem dat woorde (in hierdie geval die Griekse woord gyne) dieselfde is as die begrip of saak waarom dit gaan. Dan word 'n "historiese" beeld gebou uit dié kulturele en religieuse sfere wat as belangrik vir die Nuwe Testament beskou word - o a die "Ou Testament". So ' $n$ historiese beeld gaan dikwels, soos in hierdie geval (maar darem nie altyd nie), bowendien mank aan innerlike gebreke. En dit word dan beskou as die teologiese refleksie van die $\mathrm{Ou}$ Testament (= die Ou-Testamentiese literêre produkte) oor die onder- 
werp. Maar hierdie benadering kan nie standhou nie. Woorde is nie begrippe nie; wat ou Israel in die geskiedenis gedoen het, is nie dieselfde as die teologiese boodskap van stukke letterkunde nie. As buite-Bybelse bronne net so bruikbaar is vir die rekonstruksie van 'n kultuurgeskiedenis, moet hulle dan net soos die Bybel gebruik word?

Die onhoudbaarheid van so 'n onkritiese reeks aanvaardings in 'n "teologiese woordeboek" kan met mini-voorbeelde geillustreer word: Debora kon as rigteres 'n bepaalde gesagsposisie in ou Israel handhaaf; Israel is die Godsvolk; dus mag vrouens gesagsposisies in die kerklike Godsvolk beklee. Vrouens is uitgesluit uit die priesterskap; priesters funksioneer in die erediens; dus mag vrouens nie in die nuwe Godsvolk se erediens 'n amp beklee nie. Watter een is nou reg? Die vrou word darem ' $n$ mindere dienswerk in die tabernakel toegelaat; dus mag sy wel een of ander amptelike dienswerk in die kerk verrig - miskien die diakensamp? Dan is daar ' $n$ hiërargiese orde in die ampte moontlik. Hiermee sê ek nie dat sulke afleidings deur die ThWNT self gemaak word nie. Die Wörterbuch beweer egter wel dat hy "teologiese gegewens" verskaf. Maar as die gegewens in die "teologiese woordeboek" wel alles "teologies" sou wees, sou dit die deur open vir sulke onhoudbare konklusies. Dat dit wel gevaarlik is, blyk o a uit die Bevestigingsformulier vir ouderlinge en diakens waar die onderskeid tussen die predikantsamp en die ouderlingsamp verbind word aan die $\mathrm{Ou}$-Testamentiese onderskeid tussen die priesters en die "gewone Leviete". Hier kan mens wel redeneer dat die Formulier alleen vergelykend en illustratief na die Ou-Testamentiese onderskeid verwys, maar dit is te betwyfel of hierdie uitvlug sonder geforseerdheid volgehou kan word (terwyl die wysheid daarvan om 'n hiërargiese priester-Leviet-verhouding vir 'n uitgesproke anti-hiërargiese predikant-ouderling-verhouding te gebruik, ook bevraagteken kan word).

Hiermee het ons reeds gekom by die tweede benaderingswyse t o v ons probleem wat ek wil uitwys. Ons kan dit die biblisistiese benadering noem. Hier word dit nodig geag dat vir elke teologiese beslissing van die kerk ' $n$ "bewysplaas" aangedui sal word. Daar moet, om so te spreek, 'n "teks" wees vir elke theologoumenon van die kerk. Jesus se grootdoop is die teks vir die grootdoop van vandag. Of, in omgekeerde rigting, as die kerk predikante, ouderlinge en diakens ken, moet daar ten minste een teks wees wat bewys dat net hierdie drie ampte permanent is en dat al die ander bedieninge òf tydelik was òf onder een of meer van hierdie kategorieë tuisgebring kan word. Al wat mens kan respekteer in so 'n fundamentalistiese benadering, is die hoë agting vir die Bybel. Maar die wyse waarop die Bybel gebruik word, is niks anders nie as 'n tegniek om hom te laat sê wat die gebruiker wil hoor. Daar is geen oog vir die historiese be- 
paaldheid van die Bybelse literatuur nie, ook nie vir die genres daarvan nie, en daarom ook nie vir die funksie en betekenis van wat daardie literatuur wil sê nie. Soos James Barr in sy boek Semantics of biblical language betoog, word daar ook eklekties gebruik gemaak van alleen dié gedeeltes wat die leser pas wanneer mens nie 'n wetenskaplik verantwoorde metode het om literêre tekste se betekenis vas te stel nie.

Toegepas op ons probleem, sou soos volg geredeneer kan word: Ons ken die motiewe koningskap, priesterskap en profesie uit die Nuwe Testament (I Pet 2:9; I Kor 12:10). Hierdie motiewe kom ook in die Ou Testament voor. Beide testamente is die geinspireerde woord van God. Derhalwe moet die motiewe koningskap, priesterskap en profesie in die Ou Testament kwalitatief op dieselfde vlak lê as die gebruik van dié motiewe in die Nuwe Testament. Die profeet se werk is om Gods woord te verkondig, die priester s'n om kultiese diens te verrig en die koning s'n om in Gods opdrag oor sy volk te regeer (hier word dus die skyn gewek van waardering vir konteks en historiese bepaaldheid - maar dit is net oëverblindery). Daarom kan dié Ou-Testamentiese motiewe as ampte vertolk word en as sodanig gebruik word om die gemeenskaplike element in die Ou-Testamentiese dienswerk en die kerklike dienswerk te onderbou. Dan word gemeen dat ' $n$ Ou-Testamentiese basis vir die kerklike ampte gevind is. Behalwe die gebreke hiervan waarop ek reeds gewys het, bring dit ook praktiese verleenthede in die toepassing mee. Alleen die predikantsamp kan op hierdie wyse "gefundeer" word, want alleen hy kan sowel "profeet" as "priester" as "koning" wees. Die ouderling mag nie 'n "priester" wees nie want hy is 'n "gewone Leviet". As die teenargument kom dat al drie die "Ou-Testamentiese ampte" in die "Nuwe-Testamentiese amp" verenig is en nie in die amp van die ouderling of diaken (wat heeltemal buite die prentjie bly) nie, sal daar beswaarlik verweer wees teen die kritiek van eklektisisme. Wanneer die innerlike logika van fundamentalistiese redenasie konsekwent deurgevoer word, word die absurditeit van sy posisie gou duidelik ten spyte daarvan dat dit op die eerste blik gekamoefleer kan word (wat ook goed geillustreer word in Barr se pas verskene boek Fundamentalism). Om hierdie redes wil ek met klem ondersteuning gee aan die bedenkinge wat professor Pelser op die Predikantevergadering van 1976 uitgespreek het teen die geforseerde konstruksie van 'n Ou-Testamentiese onderbou vir die kerklike ampsteologie. As die uitsprake wat (tereg of ten onregte) oor koningskap, priesterskap en profetedom aan die Nuwe Testament ontleen is, in die $\mathrm{Ou}$ Testament teruggedra word, lei dit tot wat ek pas gekritiseer het ook al word die ooglopende absurde trekke daarvan ontken of verswyg. As die terugdrategniek wettig sou wees, sou die beslissing oor 
die vrou in die predikantsamp reeds gevel wees: Vroulike profete, vroulike predikante.

Voordat ek my eie standpunt bied, wil ek wys op 'n interessante projek wat tans onder leiding van Kirsten Nielsen aan die Universiteit van Aarhus in Denemarke van stapel gestuur word. Dit is 'n projek wat die onderwerp "Die vrou in die Ou Testament" bestudeer. Daar is nog niks gepubliseer nie, maar Nielsen het my onlangs op die Internasionale Ou-Testamentiese Kongres in Göttingen oor hul werkswyse ingelig. Dit gaan hier nie bloot om die kultuurhistoriese posisie van die vrou in Israel nie, maar dáárom dat tekste waarin vroue figureer, literêr ondersoek word sodat vasgestel kan word hoe die interpretasie van die vrou in sulke Ou-Testamentiese tekste daar uitsien. Dit is dus 'n streng literêr-eksegetiese projek. Ons kan uitsien na die voltooiing daarvan en die publikasie van die resultate, aangesien ons kan vermoed dat daaronder ook gegewens sal voorkom wat vir ons spesifieke huidige probleem van belang sal wees.

Uit alles wat ek tot dusver betoog het, sal seker blyk dat ons $\mathrm{m}$ i alleen op een manier kan vasstel watter relevante gegewens vir ons probleem in die Ou Testament voorkom en welke betekenis dit vir die teologiese besinning oor die saak het. En dit is om die geskrewe tekste van die Ou Testament literêr te ondersoek. 'n Paar jaar gelede het ek 'n studie gemaak van die aspekte van menslike mag in die $\mathrm{Ou}$ Testament. Die navorsing daarvoor het my die geleentheid gebied om ook dié gedeeltes te vind wat vir my huidige opdrag belang het. $M$ i word daar nêrens in die Ou Testament ' $n$ besinning gebied oor die vrou se religieuse funksie in die geloofsgemeenskap van die gemeente van Yahweh nie. Haar uitsluiting uit die priesterskap is net so min 'n beroepsgrond vir die uitsluiting van die vrou uit die predikantsamp as wat die uitsluiting van dogtertjies uit die besnydenis' $n$ beroepsgrond is vir hul uitsluiting uit die doop. So sal ons dan met breëre perspektiewe moet werk.

Dit beteken dat ons dié gedeeltes sal moet ondersoek waar ons die vrou as deurdagte literêre motief vind, $\mathrm{d} \mathrm{w} \mathrm{s}$ in kontekste waar oor haar as mens besin word. Dit sluit dus onmiddellik dié gedeeltes uit waar haar regsposisie in die juridiese ordening van Israel gereël word, sowel as dié gedeeltes waar ons ' $n$ insidentele blik kry in haar eventueel suksesvolle deelname aan die openbare lewe, en ook dié tekste waar sy 'n blote literêr-tegniese funksie vervul. Na my mening laat dit ons hoogstens met ' $n$ aantal wysheidstekste en die paradysverhaal.

Ruimte ontbreek om die fynste besonderhede in die wysheidstekste van die Spreukeboek te behandel. Daarom gee ek alleen ' $n$ oorsig. In die boek Spreuke vind ons sowel aforistiese literatuur (kort spreuke) as langer wysheidskomposisies. In biede hierdie literatuur- 
tipes figureer die vrou onder twee aspekte, $\mathrm{nl}$ die goeie vrou en die slegte vrou. Die slegte vrou word gemanifesteer in die ontugtige vrou $(22: 13 ; 23: 27 ; 28 ; 30: 32$ - aforismes: $2: 12 \mathrm{vv} ; 5: 1 \mathrm{vv} ; 6: 20 \mathrm{vv}$; 7:6 v v - langer komposisies). Die jongman word herhaaldelik teen haar verleidelikheid gewaarsku. Die slegte vrou word egter ook gemanifesteer in die verstandelose en twisgierige vrou $(11: 22 ; 27: 15)$ net soos die dwase en twisgierige man. Daarteenoor verneem ons sowel in die aforismes $(12: 4 ; 14: 1 ; 18: 22)$ as in die langer komposisies (31:10-31) van die goeie vrou. Sy word as hulp vir haar man voorgestel, ' $n$ gawe van Jahwe genoem (18:22), en as produktiewe versorgster van haar huisgesin geteken, terwyl haar barmhartigheid teenoor armes ook as aspek van haar wysheid besing word (31:10). In die wysheidsliteratuur word daar dus nie uitsprake gevind oor "die vrou" as sodanig nie, maar oor bepaalde kategorieë van vroue. Dit korrelleer met die algemene kategorieë "wyse" en "dwase" waarvan die Spreukeboek vol is. Wysheid beteken hier om by Gods orde in te skakel deur in harmonie daarmee op te tree, en dwaasheid beteken om dié orde deur optrede te versteur. Tot eersgenoemde word opgeroep en teen laasgenoemde word gemaan. By hierdie opset pas ook die uitsprake oor die vrou in. Sy is alleen waardevol wanneer sy aan die wysheidsnorme voldoen. Dus word sy in die wysheidsliteratuur aan 'n funksionele maatstaf gemeet. Presies dieselfde geld van die man. Daarom kan ons sê dat die vrou in die grond van die saak net soos die man beoordeel word.

Nou kom ons by die paradysverhaal van Genesis $2: 4 \mathrm{~b}-3: 24$. Na my mening vind ons hier die enigste teologiese refleksie in die $\mathrm{Ou}$ Testament op die vrou as mens. Die paradysverhaal bestaan uit twee hoofafdelings: A (2:4b-25) oor hoe die mens in die paradys gekom het, en $B(3: 1-24)$ oor die verdrywing van die mens uit die paradys. In beide hierdie afdelings figureer die vrou as 'n deurdagte literêre motief, en wel op ' $n$ besonder effektiewe manier wat inpas by die verhouding van die hele deel $A$ tot die hele deel $B$. Hoewel ek natuurlik met die totale konteks moes reken by die eksegese daarvan, konsentreer ek nou in my bespreking op dié dinge wat vir ons onderwerp van belang is.

In afdeling A word die ontstaan van die vrou en Gods motivering daarvoor ingebou in 'n konteks oor die formasie van die mens en sy plek in die skepping. Die eerste subseksie A1, (naamlik verse 4b-7) gaan oor die aanvanklike chaos en die formasie van die mens. A2 (verse 8-15 plus 16-17) gaan oor die tuin wat God georden het en die aanstelling van die mens daaroor plus die voorskrif oor wat geëet mag word en wat nie (wat in afdeling B van groot belang word). Dan volg A3 (verse 18-25) oor die formasie van die vrou en haar aanvaarding deur die man plus 'n konklusie oor die eenheid van die twee en hulle naaktheid. Nou is die struktuur hier besonder merkwaardig en 
effekvol. Daar word naamlik 'n klimaktiese struktuur gebou. Eers sê God dat die mens nie alleen behoort te wees nie en dat hy 'n hulp moet kry wat by hom pas (vers 18). Maar dan word vermeld dat God die diere en die voëls geformeer het en hulle na die mens gebring het om te sien hoe hy hulle sou noem. Vervolgens word uitvoerig vertel dat die mens hulle inderdaad name gegee het. En eers dàn word die motief van die passende hulp weer opgeneem. Die hele onderneming met die diere hou verband met die soeke na 'n passende hulp vir die man, maar daar kom niks van nie. So word van die bekende literêre tegniek van retardering of vertraging gebruik gemaak waardeur spanning opgebou word sodat 'n klimaks geskep kan word. Dit word bevestig deur die eerste woorde wat ons van die man verneem. Wanneer hy haar aanvaar, maak hy sy debuut in poësie, nie prosa soos alles wat voorafgaan nie. Reeds Hermann Gunkel het daarop gewys dat hierdie verskynsel by die hóógtepunt van 'n vertelling voorkom. Ook die driemalige herhaling van $z \bar{o}^{-\prime} t$ in sy woorde beklemtoon die intensiteit van die twee versreëls. Verder kontrasteer hy haar met die diere deur die "Verwandtschaftsformel" soos W Reiser (sien Westermann se kommentaar i.l.) dit noem. Sy is die man se eie vlees en bloed - sy gelyke, in teenstelling tot die diere. Die vyfde aanduiding van die klimaktiese posisie van die vrou lê in die man se uitroep happacam, "hierdie keer eindelik". Hierby kom ten slotte nog haar benaming: 'iššă wat' $n$ spel op die man se naam is: 'iššă is die vroulike vorm van ' $\imath s$, "man" - man en mannin. Al hierdie literêre gegewens toon dat die vrou die hoogtepunt van die skepping is. Dit beteken dat die vrou as mens besonder positief gewaardeer word. Westermann noem dit 'n bewussyn van die hoë "Bedeutung der Frau für das Menschsein des Menschen" en 'n totale gelyke gemeenskap tussen beide. Op hierdie gronde het ook Van Ruler gelyk wanneer hy êrens sê dat die vrou die éíntlike mens is. Tereg wys Westermann ook daarop dat die waardering van die vrou in die moderne westerse kultuurkring merkwaardig ooreenstem met wat hier oor die verhouding man-vrou gesê word. Hieruit moet ons konkludeer dat daar geen gronde is vir die teengestelde interpretasie in die Huweliksformulier nie - waar die vrou aangesê word om stil te wees "want Adam is eerste gemaak, daarna Eva as 'n hulp vir Adam". (I Timoteus 2:12-13 word hier buite rekening gelaat omdat dit nie binne my opdrag val nie. Ek mag wel opmerk dat interpretasie van die Ou Testament en interpretasie van die Nuwe-Testamentiese gebruik van die Ou Testament twee verskillende sake is.) Dit is die indra van 'n subjektiewe oordeel van buite die teks. Daar word veronderstel dat die verhouding eerste-laaste 'n rangorde beteken, en geen rekening gehou met die feit dat die patroon eerste-laaste ook klimakties kan funksioneer nie - wat juis om bogenoemde redes hier die geval is. Bowendien kan mens dan vra wat ons met Genesis 1 
moet maak waar die diere eerste gemaak is en daarna die mens!

In die tweede hoofafdeling van die paradysverhaal (B) figureer die vrou ook. Hierdie afdeling is uit drie subseksies opgebou (ek laat die onderafdelings ter wille van ruimte daar). Eerste (B1) kom haar gesprek met die slang (3:1-5) plus die eet van die verbode vrug (verse 67). Dan volg in B2 die ontmoeting met God, ontdekking, ondervraging, verdediging en oordeel (verse 8-19). En laaste (B3) kom die afloop en verdrywing uit die paradys (verse 20-24). Ook hier het ons 'n fyn gekomponeerde stuk. Die volgorde waarin die partye ingevoer word, word simmetries gerangskik: In B1 slang-vrou-man, in B2 omgekeerd man-vrou-slang, en dan slaan dit in B3 weer terug na die eerste patroon, naamlik slang-vrou-man. Hier word ons aandag nou gefokus op die veroordelingswoorde.

Weer vind ons poëtiese uitsprake in 'n prosa-konteks. So word dus ook in die tweede afdeling ' $n$ brandpunt geskep. Stilisties het ons in die geval van die slang en die man te doen met vervloekingswoorde, maar nie in die geval van die vrou nie. Die vervloekingswoord in die man se geval word egter op die aarde betrek en nie op homself nie. Dus word alleen die slang vervloek, en nie die man of die vrou nie. Daarom moet ons in die slang se geval van' $n$ vervloeking praat, maar in die geval van die man en die vrou van strafwoorde. Die slang se straf bestaan uit drie elemente (hy seil op sy pens, hy eet stof, en stryd kom tussen hom en die mensegeslag). Die man se straf bestaan uit die elemente moeitevolle arbeid, wat ook in verband gebring word met sy voedsel, en sy terugkeer na die stof. Tussenin staan nou die vrou se straf. Dit word geformuleer in twee merkwaardige versreëls, elk bestaande uit twee vershelftes. Hulle is parallel gestruktureer: Die vrou baar kinders // sy het moeite; sy verlang na haar man // sy word deur hom oorheers. Vanweë hierdie fyn komposisie stel ons teks sy saak in 'n uitkringende parallelisme. Die eerste reël se parallelisme is sinoniem: Die vrou het moeite by die skenk van lewe (soos die man in die volgende gedeelte moeite het by die produseer van lewensmiddele). Maar die tweede reël se parallelisme bevat ' $n$ spanning: Sy verlang na haar man maar sy word deur hom oorheers. Hier is dus nie drie "Tatsächlichkeiten" soos Von Rad in sy kommentaar sê nie (swangerskap, verlange en vernedering), maar twee aspekte van een saak, nl die vrou-wees onder die gesigspunte van moeder en eggenote (sien Westermann se kommentaar i.l., en Aspekte van menslike mag in die Ou Testament, p 159). Nadat die man sy straf aangehoor het, gee hy vir die tweede keer'n naam aan sy vrou. Dit vorm die teenhanger van die benaming wat hy in afdeling A vir haar bedink het. Nou is sy nie meer mannin, "vroulike man" nie, maar haww $\bar{a}$, lewegeefster. Dus interpreteer hy die straf van die vrou wat haar moeitevolle moederskap ingehou het. Daarmee toon hy dat hy verstaan het wat sy vrou se straf beteken en so word die belang 
daarvan onderstreep. Ons kan sê dat hierdie reaksie van die man weer die posisie van die vrou beklemtoon, wat nogeens ' $n$ teenhanger is van haar beklemtoning in afdeling A.

So kom daar dus 'n spanning tot stand tussen wat hier in afdeling $B$ oor die vrou gesê word en wat in afdeling A oor haar gesê word. En dit pas nou presies in by die groot, oorkoepelende spanning wat so sorgvuldig tussen beide afdelings van die paradysverhaal as geheel gebou is. Aan die een kant hoe die mens in die paradys gekom het; aan die ander kant die verdrywing van die mens uit die paradys. Aan die een kant ontstaan harmonie; aan die ander kant oordeel en disharmonie. In hierdie groot kontras is ook die uitsprake oor die vrou ingebou: Aan die een kant skeppingshoogtepunt, die kroon van die man, die eintlike mens; aan die ander kant die veroordeelde, die lydende, die oorheerste. In die konteks van oordeel vir haar ongehoorsaamheid figureer haar oorheersing deur die man dus as straf. Selfs nie die mees fundamentalistiese eksegeet sal kan beweer dat die vrou se oorheersing deur die man ' $n$ "skeppingsordinansie" van God of iets dergeliks is nie. In hierdie geweldige stuk letterkunde het ons dan ' $n$ teologiese interpretasie van die vrou se posisie in die wêreld as die direkte gevolg van die sonde.

Maar die laaste vraag is wat die resultaat van hierdie eksegese nou vir òns sê. Wanneer ons die Ou-Testamentiese paradysverhaal retrospektief in die lig van die volheid van Christus stel, hou dit die volgende in: Christus het gekom om die breuk wat die mens veroorsaak het (afdeling B), te herstel. Hy het die oordeel van God op Hom geneem, en die disharmonie weggeneem. En so het Hy 'n nuwe ontstaan moontlik gemaak, 'n nuwe skepping, opnuut harmonie (afdeling A). Daarom het Christus die mens van afdeling $B$ terugverplaas na afdeling $A$. Die man-mens kry vergifnis, word herskep, en die oordeel oor hom word in 'n nuwe dimensie getransponeer: Moeitevolle geswoeg word sinvolle arbeid, dood word deur die lewe oorwin. En die vrou-mens kry ook vergifnis, word ook herskep, die oordeel oor haar word ook in die nuwe, herstelde dimensie getransponeer: Haar ${ }^{c} i s ̦ s ̦ a b o \bar{n}$, moeite, word net soos die man se ${ }^{c} i s ̦ \widehat{a} \bar{b} \bar{n}$ van die oordeelskarakter bevry, en haar oorheersing deur die man word oorwin deur haar oorspronklike posisie as kroon van die skepping. Ook vir haar geld "paradise regained" ná "paradise lost". Deur Christus word sy weer die éíntlike mens soos sy in afdeling A was. Want Christus het nie alleen party dele of party motiewe van die Ou Testament vervul nie, maar alles. Daarom kan verantwoorde teologie nie alleen konsentreer op hoe Christus die màn se straf van afdeling $B$ na die heil van afdeling A omgekeer het nie. Presies net so het Hy ook die vrou se straf omgekeer na haar heilvolle heerlikheid van vroeër. Die oorheersing van die vrou deur die man, die inhibisie van haar 
situasie in enige opsig deur dié van die man, kan alleen sonder Christus gehandhaaf word.

En hierdie geweldige perspektief wat Christus se vervulling van die Ou Testament open, kan nie geïgnoreer word deur die kerk wie se voedingsbron die woord van God is nie. Wanneer ons uitsprake wil maak oor die vrou en haar bevoegdhede in die kerk, moet ons hierdie Bybelse visie verdiskonteer: In Christus, die Heer van die kerk, is daar geen man of vrou meer nie. As dan van my verwag word om die Ou-Testamentiese lig te laat val op die probleem van die vrou in die kerklike amp, kan ek net een konklusie aanbied: Die Ou Testament bied geen grond om in 'n Bybelse ampsteologie die vrou uit enige van die ampte te weer nie. As die kerk haar wel uit die ampte wil weer, sal hy nie alleen Nuwe-Testamentiese tekste daarvoor moet gaan soek nie, maar ook moet verantwoord hoe dié besinning van die Ou-Testamentiese deel van Gods woord daarin 'n onderdak kan kry. 